\title{
A Systematic Literature Review of the Impact of COVID-19 Lockdowns on Air Quality in China
}

Aerosol and Air Quality Research

\section{OPEN ACCESS}

Received: November 19, 2020

Revised: March 24, 2021

Accepted: April 4, 2021

\section{${ }^{*}$ Corresponding Author: gowj@usq.edu.au}

\section{Publisher:}

Taiwan Association for Aerosol Research

ISSN: $1680-8584$ print ISSN: 2071-1409 online

(c) Copyright: The Author(s). This is an open access article distributed under the terms of the Creative Commons Attribution License (CC BY 4.0), which permits unrestricted use, distribution, and reproduction in any medium, provided the original author and source are cited.

\author{
Rezwanul Hasan Rana ${ }^{1}$, Syed Afroz Keramat ${ }^{1}$, Jeff Gow ${ }^{1,2^{*}}$ \\ ${ }^{1}$ School of Commerce, University of Southern Queensland, Toowoomba, Queensland, Australia \\ ${ }^{2}$ School of Accounting, Economics and Finance, University of KwaZulu-Natal, Durban, South \\ Africa
}

\section{ABSTRACT}

This literature review systematically examines the effect of COVID-19 lockdowns on pollutant concentrations in China by synthesising the reported evidence. Following PRISMA guidelines, we used predefined eligibility criteria to search the databases of PubMed, Scopus, Web of Science and EBSCO Host for peer-reviewed published literature that investigated the nexus between COVID-19 and air quality in China. After screening the titles, abstracts and full texts of the retrieved results, two reviewers independently evaluated the relevant data. 35 of 508 studies met our criteria. The majority of the eligible studies reported data from central China (e.g., Wuhan and Hubei Province), and the most frequently measured air pollutant was nitrogen dioxide $\left(\mathrm{NO}_{2}\right.$; 51 values in 28 studies), followed by fine particulate matter ( $\mathrm{PM}_{2.5} ; 49$ values in 26 studies). We found evidence of a substantial reduction in air pollution immediately after lockdown measures were implemented, with traffic-related $\mathrm{NO}_{2}$ exhibiting the largest decrease. The reported reductions in air pollution varied by region and period. Specifically, urban, industrial and highly populated areas of China experienced greater improvements in air quality than rural, residential and less populated areas. Additionally, owing to meteorological factors, the effects differed between inland and coastal regions. However, despite the changes, the pollutant concentrations in many regions (e.g., Beijing, where $\mathrm{PM}_{2.5}$ and $\mathrm{PM}_{10}$ levels remained above $100 \mu \mathrm{g} \mathrm{m}^{-3}$ ) still exceeded the World Health Organization (WHO)'s 24-hour mean guidelines (e.g., $25 \mu \mathrm{g} \mathrm{m}^{-3}$ and $50 \mu \mathrm{g} \mathrm{m}^{-3}$ for $\mathrm{PM}_{2.5}$ and $\mathrm{PM}_{10}$, respectively). Without the support of adaptive environmental strategies, the recent gains in air quality will be unsustainable.

Keywords: Air pollution, Air contamination, Atmospheric environment, Coronavirus, 2019-nCov

\section{INTRODUCTION}

The first novel coronavirus (COVID-19) outbreak was reported in Wuhan, China, in December 2019 (Filonchyk et al., 2020; He et al., 2020; Le et al., 2020; Ghahremanloo et al., 2021). Subsequently, COVID-19 has become a serious public health threat worldwide as it transmitted rapidly and caused millions of infections and deaths, especially among the elderly. Therefore, it has been declared as a global pandemic by the World Health Organization (WHO; Gautam, 2020). As of 23 March 2021, COVID-19 had affected 124 million people in 192 countries and territories with 2.7 million deaths around the world (Johns Hopkins University, 2021).

COVID-19 is an infectious disease that transmits from human to human through direct contact, droplet and aerosol transmission (Fernandez-Montero et al., 2020; Wang and Du, 2020). To prevent the spread of this infectious disease, the Chinese government took a nationwide contingency plan (followed by other nations) to restrict human activities. More specifically, the Chinese government implemented widespread restricted road traffic and human activities in late January to early February 2020 (Chen et al., 2020c). Similar measures have been taken by most of the countries of the world in the form of restricted transportation, and closing of business, economic, social, educational, cultural and recreational activities to control the transmission of the virus 
(Dantas et al., 2020). During the lockdown, economic activities decreased dramatically, and people were isolated in their homes. Within a short period of time, environmental researchers noticed the positive side effect of the lack of human economic activity. Lockdown measures resulted in the improvement in air quality, as air pollutants such as particulate matter with a diameter of 10 $\mu \mathrm{m}$ or less $\left(\mathrm{PM}_{10}\right)$, particulate matter with a diameter of $2.5 \mu \mathrm{m}$ or less $\left(\mathrm{PM}_{2.5}\right)$, sulphur dioxide $\left(\mathrm{SO}_{2}\right)$, carbon monoxide (CO), and nitrogen dioxide $\left(\mathrm{NO}_{2}\right)$ decreased significantly (Fan et al., 2020a; Filonchyk et al., 2020; Lian et al., 2020; Nichol et al., 2020; Pei et al., 2020).

Air pollution is a significant environmental health threat to humans. According to the WHO (2016), ambient air pollution caused 4.2 million deaths worldwide and 81 deaths per 100,000 population in China in 2016 (WHO, 2016). Air pollution is a serious concern in China (Dong et al., 2019). In 2016, the country contributed $33 \%, 24 \%$, and $31 \%$ of the world's total emissions of $\mathrm{SO}_{2}$, $\mathrm{NO}_{2}$, and $\mathrm{CO}$, respectively. Nationwide social lockdowns imposed by the national and provincial Chinese governments created an opportunity to evaluate changes in air quality. It is assumed that a decrease in human activities reduce pollutant levels in the atmosphere significantly.

The impact of lockdown on China's air quality, which has a significant effect on global air quality, cannot be ignored. This positive impact of lockdown in terms of improvement in air quality in China (ranked $11^{\text {th }}$ based on the average PM $_{2.5}$ exposure) has not yet been identified adequately in the existing literature. In addition, there are significant heterogeneities in reported changes in the concentration of air pollutants in China during COVID-19 lockdowns. This calls for a comprehensive synthesis of the existing research. Several recent studies called for further research on this context (Chen et al., 2020c; Ming et al., 2020). There are several reasons for selecting China as the study setting. Firstly, with almost 1.4 billion people, China is the most populous country in the world (World Bank, 2017). Secondly, 48 Chinese cities featured among the 100 most polluted cities globally in 2019 (IQAir, 2020). Thirdly, China has an advanced nationwide air pollution monitoring system ensuring the availability of meticulous data (IQAir, 2020). Lastly, due to the COVID-19 outbreak, China imposed very strict lockdown measures in many cities and regions. Therefore, this study attempts to analyse evidence from scientific research articles on the extent of the improvement in China's air quality due to COVID-19-related lockdowns.

The objective is to provide a quantitative as well as a narrative synthesis of the recent evidence from the published literature that reported on changes in air quality in China during COVID-19 lockdowns. Given the differences in the impacts of partial or full lockdown on China's air quality at the national, provincial and regional level, the current study presented a systematic literature review based on a comprehensive analysis of 35 research articles published since February 2020.

This study considered two key issues: Did partial or full COVID-19-related lockdowns improve China's air quality significantly? And what is the level of improvement in air quality measured in terms of the reduction of $\mathrm{PM}_{2.5}, \mathrm{PM}_{10}, \mathrm{SO}_{2}, \mathrm{CO}$, ozone $\left(\mathrm{O}_{3}\right)$ and $\mathrm{NO}_{2}$ and does it differ across China? The findings of this study may serve as reference for improvement in air quality due to lockdown measures and thus be helpful to policymakers for post-pandemic air quality management.

\section{METHODS}

\subsection{Literature Search}

The preferred reporting items for systematic reviews and meta-analysis (PRISMA) guidelines were used to conduct this systematic literature review (McInnes et al., 2018). The PRISMA approach provides strategies for a detailed database search using selected search terms and a set of predetermined inclusion and exclusion criteria (Shaffril et al., 2018). The authors conducted a systematic review of the articles that focused on and reported changes in air quality during COVID-19 lockdown in Chinese cities and provinces. The online databases of EBSCO Host, PubMed, Web of Science, and Scopus were searched from inception to 10 September 2020. The following pollutants were considered as a measure of air quality: $\mathrm{NO}_{2}, \mathrm{PM}_{2.5}, \mathrm{PM}_{10}, \mathrm{SO}_{2}, \mathrm{CO}, \mathrm{O}_{3}$ and air quality index (AQI) (Xiong et al., 2020).

\subsection{Eligibility Criteria}

This study included journal articles that estimated variations in air quality in China using the following criteria: 1) the peer-reviewed published article was original; 2) the study included at 
least one Chinese city or province; and 3) the study included quantitative measures or results of at least one of the air pollutants. Studies estimating only the outdoor air quality were included in the review, and the study did not apply any limitations regarding study design or time. Finally, studies that did not quantitatively estimate and report the change in air quality were also excluded from this study. Table 1 lists the predetermined exclusion and inclusion criteria used in this study.

\subsection{Search Terms and Database}

Table 2 includes the complete search strategy of this literature review. Search terms included "COVID-19", "air pollution" and "China". Search terms related to these specific keywords were also included. A research librarian assisted in developing the search strategy. Based on the predetermined search strategy and the inclusion and exclusion criteria, two reviewers autonomously conducted the database search. This study identified additional literature by scanning the references (backward search) of the selected articles. Detailed search terms for specific database have been listed in Appendix A. This study used EndNote (X9) software to organise and manage the references.

\subsection{Study Selection and Data Extraction}

Two authors independently evaluated studies identified from the database search to assess their eligibility for inclusion. They reviewed the title and abstract and screened full text of the article (if required). Full-text screening was conducted for articles that met the inclusion criteria (after an initial screening of the abstract). In case there were any differences of opinion, the two authors attempted to resolve the disagreement through discussion. If no agreement could be reached a third author was involved who resolved the conflict. Two authors also screened fulltext versions of the included articles to provide independent judgment regarding their quality. Lastly, to locate potential additional studies, the reference lists of the included articles were also searched by the two authors independently.

The authors extracted the following data from the selected studies: author, year of publication, study design, study setting, time comparison, and key findings related to air pollutant measures. One author conducted the data extraction using the PRISMA guidelines (McInnes et al., 2018) and others verified the extraction of data from the selected studies.

\subsection{Assessment of Study Quality}

To evaluate the quality of the included studies, this study used the Strengthening the Reporting of Observational Studies in Epidemiology (Cardona et al., 2013) statement checklist (von Elm et al., 2007). 15 tools from the STROBE checklist were used: background, objective, setting, participants, data source, study size, quantitative variables, statistical method, sensitivity analysis, descriptive

Table 1. Inclusion and exclusion criteria.

\begin{tabular}{|c|c|c|}
\hline Criterion & Eligibility & Exclusion \\
\hline Literature type & $\begin{array}{l}\text { Peer-reviewed published journal } \\
\text { articles. }\end{array}$ & $\begin{array}{l}\text { Book, book series, chapter in book, conference proceeding, } \\
\text { online report, short comments, correspondence, short } \\
\text { points, reviews or letters, invited editorials, pre-prints } \\
\text { without peer review, letter to the editor or editorials that } \\
\text { summarised the results of the included articles. }\end{array}$ \\
\hline Language & $\begin{array}{l}\text { English (no studies were available in } \\
\text { the official language of China). }\end{array}$ & Non-English language literature. \\
\hline Country & China (mainland). & Any other country, state or region. \\
\hline Other & $\begin{array}{l}\text { Studies not focused on China; however, } \\
\text { reported results from Chinese cities, } \\
\text { provinces or regions. } \\
\text { Studies exclusively focused on outdoor } \\
\text { air quality. }\end{array}$ & $\begin{array}{l}\text { Studies focused on COVID-19 outbreak and indoor air quality, } \\
\text { meteorological parameters on the spread of COVID-19, air } \\
\text { pollution and COVID-19 infection or deaths, preventing } \\
\text { carbon emission retaliatory rebound post-COVID-19. } \\
\text { Studies that reported aggregate (global) outcomes but the } \\
\text { individual country-specific outcome was unavailable. }\end{array}$ \\
\hline
\end{tabular}


Table 2. Characteristics of the included studies.

\begin{tabular}{ll}
\hline Variables & No. of Studies (\%) \\
\hline $\begin{array}{l}\text { Study design } \\
\text { Quantitative }\end{array}$ & $35(100 \%)$ \\
Study year & $35(100 \%)$ \\
$\quad 2020$ & \\
Source of data & $12(34 \%)$ \\
$\quad$ Satellite (TROPOspheric Monitoring Instrument) & $23(66 \%)$ \\
$\quad$ Ground-level station & \\
Time compared & $8(23 \%)$ \\
Pre- and post-lockdown 2020 & $15(43 \%)$ \\
Post-lockdown 2020 with 2019 & $7(20 \%)$ \\
Post-lockdown 2020 with mean of 2017-2019 & $5(14 \%)$ \\
Post-lockdown 2020 with mean of 2015-2019 & \\
Study setting & $9(26 \%)$ \\
Nationwide & $26(74 \%)$ \\
Cities, provinces or regions & \\
Type of analysis & $28(80 \%)$ \\
Descriptive analysis & $7(20 \%)$ \\
Regression analysis & \\
Criteria pollutants & $28(80 \%)$ \\
NO & $26(75 \%)$ \\
PM2.5 & $17(49 \%)$ \\
PM10 & $17(49 \%)$ \\
SO 2 & $18(52 \%)$ \\
CO & $12(34 \%)$ \\
O $_{3}$ & $7(20 \%)$ \\
AQI &
\end{tabular}

data adjusted and unadjusted results, limitations, interpretation of findings and funding sources of the study (Items 2, 3, 5-8, 10-14, 16, 18-20, 22) (Appendix B and Appendix C). Other items from the STROBE checklist were not relevant for assessing the quality of the papers.

Two authors independently evaluated the quality appraisal, which was further verified by another author. Each item was coded $Y=$ present, $N=$ not present, $P=$ partially present or $N / A=$ not applicable. Lastly, the positive judgement percentage was calculated to demonstrate the quality of the included studies.

\subsection{Data Synthesis}

There were considerable differences in the study setting, methods, measures of outcomes, time period comparison and significant results reported in the selected studies. Hence, this study conducted a narrative and qualitative synthesis of the key findings. The data are plotted in graphs to report the percentage change in air quality at different time periods, and box plots used to show median and interquartile ranges and correlation tests were conducted to understand the relationships between $\mathrm{NO}_{2}$ and $\mathrm{PM}_{2.5}, \mathrm{PM}_{10}$ and $\mathrm{PM}_{2.5}$, and $\mathrm{SO}_{2}$ and $\mathrm{PM}_{2.5}$. The main objective was to categorise and report both qualitative summary and quantitative estimates demonstrating changes in air quality during COVID-19 lockdowns in China.

\section{RESULTS}

\subsection{Identification and Characteristics of Studies}

This study identified 500 studies through the literature search, and another eight studies were included through the backward search of the included studies. A total of 396 studies remained after duplicates (same articles from two different database searches) were removed. The authors reviewed the title and abstract of 396 articles, and screened full texts of 141 articles, amongst 
which 35 studies met the predetermined inclusion criteria (Fig. 1). Several articles were excluded, because their main focus was to examine the impact of air quality on COVID-19-related infections. Other key reasons for exclusion of articles are illustrated in Fig. 1. Nine of these reported aggregate data on China and the rest estimated air quality changes for various cities and provinces of China (Fig. 2). A majority of the studies $(n=24)$ included Wuhan (located in Hubei Province) as the primary study location.

All the studies were published in the year 2020 and quantitative in their study design (Table 2). The included studies provided air quality data in China from satellite $(n=12)$ and ground-level $(n$ = 23) stations. Further analysis revealed that studies conducting global analysis commonly used data from satellite and studies focusing on specific Chinese cities and provinces commonly used data from ground-level stations. A majority of the studies compared the lockdown period of 2020 in China with identical periods of $2019(n=15)$. Other studies compared pre- and post-lockdown periods of $2020(n=8)$, post-lockdown period of 2020 with a mean of identical periods of 2017$2019(n=7)$ or 2015-2019 ( $n=5) .26(74 \%)$ studies focused on measuring the change in air quality in specific cities, provinces and regions of China. Finally, we categorised the included studies based on types of pollutants measured. 28 (80\%) provided 51 values for $\mathrm{NO}_{2}$ and 26 (75\%) recorded 49 values for $\mathrm{PM}_{2.5}$.

\subsection{Reduction in Air Pollution}

Fig. 3 presents the dispersion of changes in the air quality measures of the included studies for all China, and the city of Wuhan and Hubei Province. The estimated median reduction for $\mathrm{NO}_{2}$, $\mathrm{PM}_{2.5}, \mathrm{PM}_{10}, \mathrm{SO}_{2}, \mathrm{CO}$, and $\mathrm{AQI}$ during COVID-19 lockdown with data from all the included studies (irrespective of the time period compared) is $45.1 \%, 26.6 \%, 31.4 \%, 31.3 \%, 20.7 \%$ and $21.7 \%$, respectively. All data box plots are comparatively short, which indicates fewer variations in the reported changes in air quality measures in China. All the means and medians are negative, which signifies improvement in air quality across China, irrespective of the time periods compared. The average reduction in all air quality measures (except for $\mathrm{CO}$ ) were higher in Wuhan and Hubei

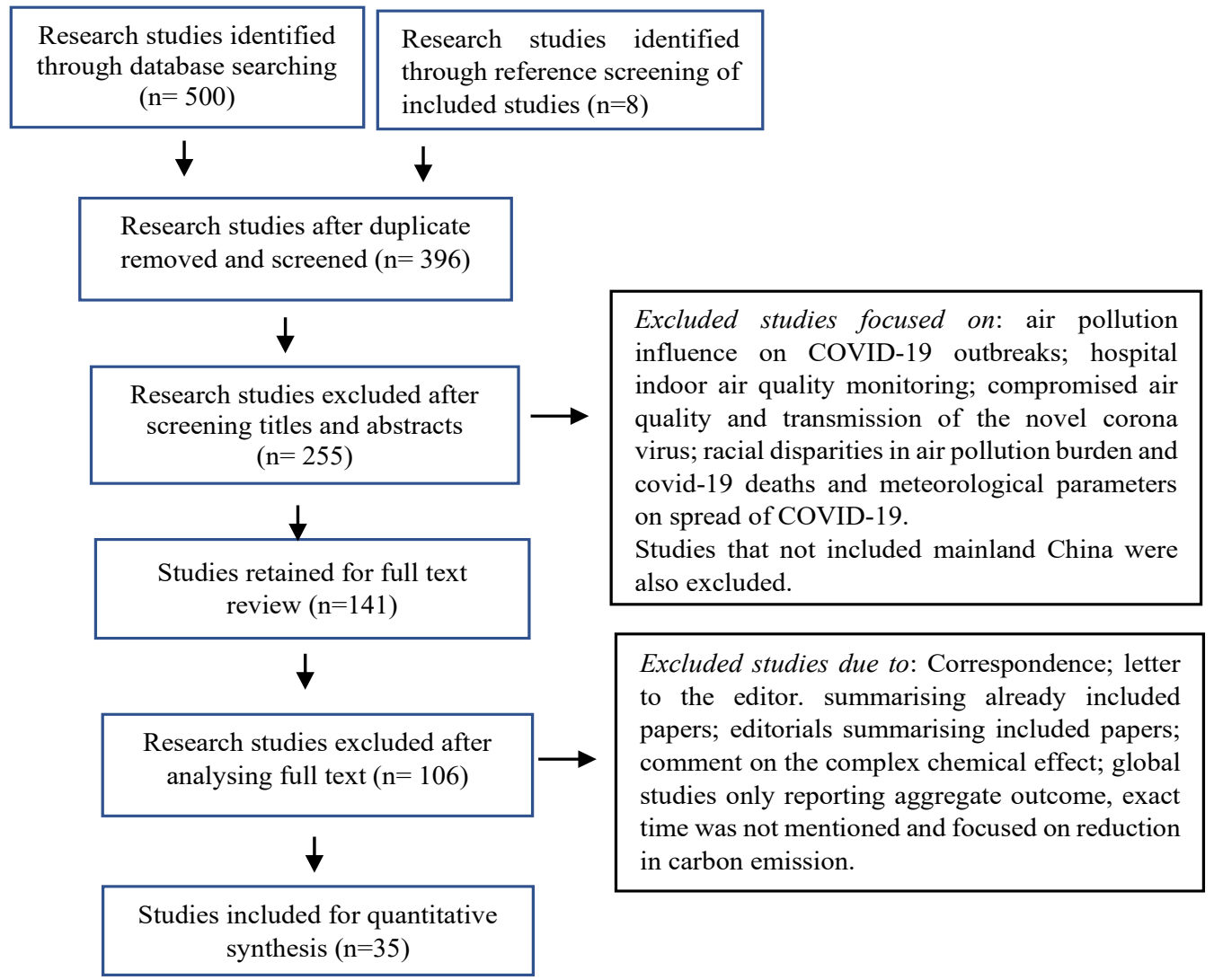

Fig. 1. Framework of the systematic literature review process. 


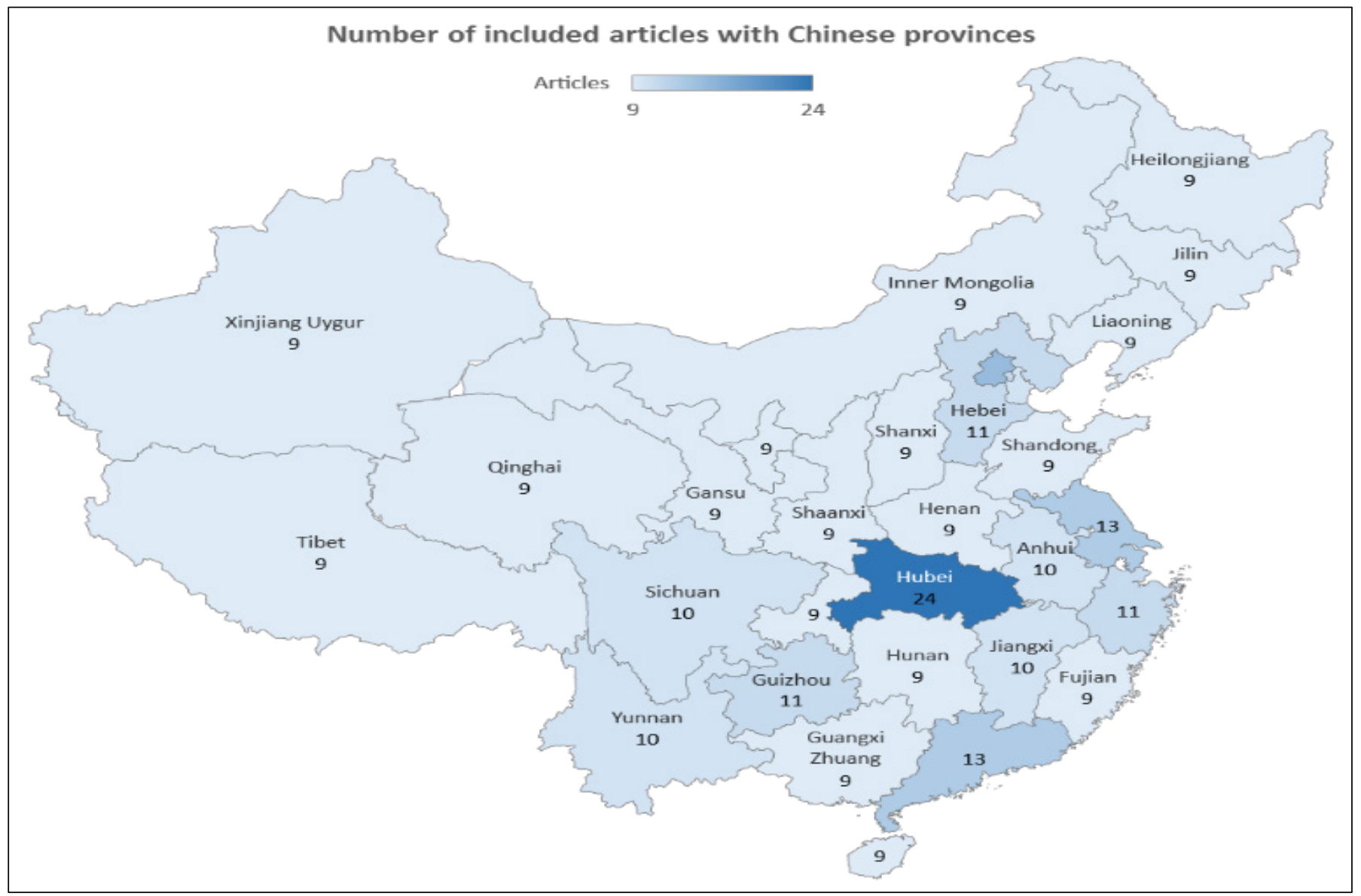

Fig. 2. Study setting of the included literature that met the inclusion criteria. Note: Several studies reported data on multiple regions.

Province $\left(\mathrm{NO}_{2}=56.7 \%, \mathrm{PM}_{2.5}=31.4 \%, \mathrm{PM}_{10}=39.0 \%, \mathrm{SO}_{2}=31.9 \%, \mathrm{CO}=16.5 \%\right.$, and $\left.\mathrm{AQI}=40.7 \%\right)$ than the average reduction in China overall. Noticeably, for Wuhan and Hubei Province, $\mathrm{SO}_{2}$ showed the highest spread among the data followed by $\mathrm{NO}_{2}$. The highest reported decrease in $\mathrm{SO}_{2}$ was 105.6\% (Zhang et al., 2020a), and the lowest was 3.9\% (Lian et al., 2020).

Table 3 depicts the percentage change in $\mathrm{NO}_{2}, \mathrm{PM}_{2.5}, \mathrm{PM}_{10}, \mathrm{SO}_{2}, \mathrm{CO}, \mathrm{O}_{3}$, and AQI for Wuhan and other major regions and cities of China. These figures also present a comparison between different time periods.

Results from aggregate outcomes (China) indicated that average $\mathrm{NO}_{2}$ and $\mathrm{SO}_{2} 60$ days after lockdown were $80 \%$ and $50 \%$ lower, respectively, than 30 days before lockdown (Fan et al., 2020a). Reduction in $\mathrm{PM}_{2.5}$ was higher (37-39\%) immediately after the lockdown (30 days following 23 January 2020); nonetheless, as the comparison time increased (60-90 days) the reported drop was $10.5 \%$ (Silver et al., 2020) to $14.8 \%$ (Wang et al., 2020b) when compared to identical dates of 2019.

In Wuhan, studies that compared post-lockdown period (23 January 2020 onwards) with prelockdown periods or identical times in 2019 or average of 2015-2019 (Table 3) reported a reduction in $\mathrm{NO}_{2}$ (45-93\%), $\mathrm{PM}_{2.5}$ (30-44\%) and $\mathrm{PM}_{10}$ (35-48.7\%). One study compared JanuaryMarch of 2020 with 2019 and found only a 25\% fall in $\mathrm{NO}_{2}$ because it included pre-lockdown period (before 23 January 2020).

For Beijing, the concentration of $\mathrm{NO}_{2}, \mathrm{PM}_{2.5}, \mathrm{SO}_{2}$, and $\mathrm{CO}$ was 25.6-38.8\%, 6.4-33.2\%, 37.1$48.1 \%$ and $11-40 \%$ lower, respectively, in 2020 compared to the same months of 2019 (Table 3). In the Yangtze River Delta (YRD) region the reduction in $\mathrm{NO}_{2}$ (27.2-45.1\%) was similar to Beijing but the drop in $\mathrm{SO}_{2}$ (7.6-20.4\%) was significantly smaller in 2020 compared to the same time in 2019. One study reported the changes in air quality in urban and rural areas of Hangzhou (Wang et al., 2020a). Post-lockdown, concentrations of $\mathrm{NO}_{2}$ (58.4\% vs. $\left.48 \%\right), \mathrm{PM}_{2.5}$ (42.7\% vs. $\left.18.5 \%\right)$, and 


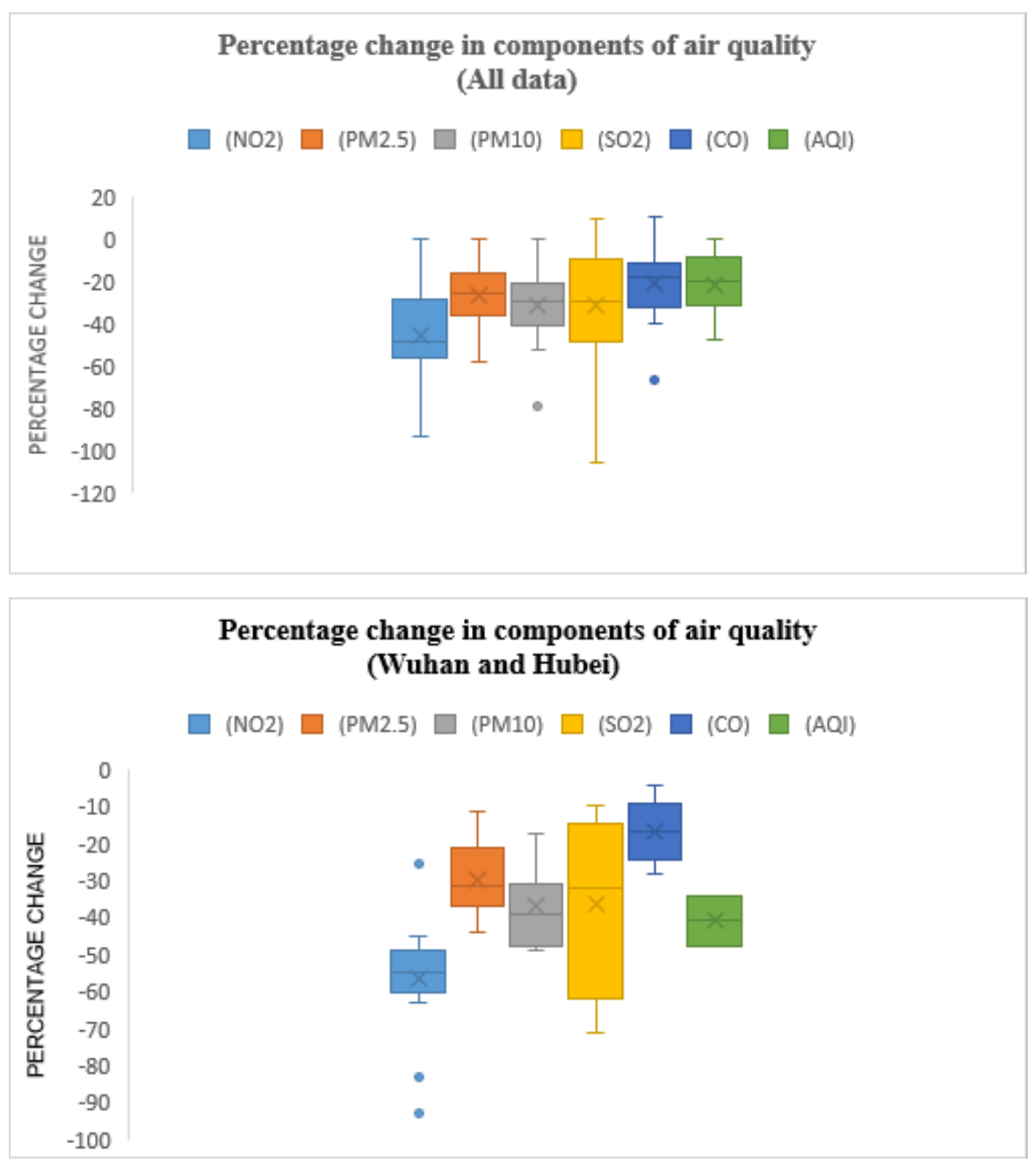

Fig. 3. Percentage change (median) in $\mathrm{NO}_{2}, \mathrm{PM}_{2.5}, \mathrm{PM}_{10}, \mathrm{SO}_{2}, \mathrm{CO}$, and AQI during COVID-19 lockdown. Note: $x$ indicates mean value, line in the middle is median value, top line of the box indicates upper quartile, bottom line of the box represents lower quartile and thus, the middle box represents the middle $50 \%$ of scores for the group. Lower whisker shows the bottom $25 \%$ (quartile group 1) and upper whisker demonstrates the top $25 \%$ (quartile group 4) values.

$\mathrm{PM}_{10}$ (47.9\% vs. 39.6\%) shrank considerably more in urban areas than rural (Table 3). Reduction in $\mathrm{NO}_{2}$ was $31.1-32.3 \%$ in Guangdong, $48.6-49.2 \%$ in Hubei, $30.1-46 \%$ in Guangzhou and $43.7 \%$ in Shanghai. In contrast, the drop in $\mathrm{PM}_{2.5}$ was $9.6-19.8 \%, 11.3-26.3 \%, 23-31 \%$ and $26.6-54.5 \%$ in Guangdong, Hubei, Guangzhou and Shanghai, respectively. The summary of the findings illustrates the percentage change in air quality in other key cities in China. All these studies reported significant reductions in $\mathrm{NO}_{2}$ (20.2-70\%), $\mathrm{PM}_{2.5}$ (7.6-49.2\%), $\mathrm{PM}_{10}$ (13.9-47.4\%), $\mathrm{SO}_{2}$ (18.9$105.6 \%)$ and CO (29.3-66.8\%). In contrast, Zhang et al. (2020a) reported an 11\% increase in CO in Luzhou, and Wan et al. (2020) and Shakoor et al. (2020) found that $\mathrm{SO}_{2}$ concentration increased by $6.3 \%$ and $10.3 \%$ in Shenzhen, respectively.

The findings also indicated the rapidness of the change in air quality across China after the lockdown. For example, in the south-western region, $\mathrm{NO}_{2}$ dropped by $49 \%$ within two weeks (Chen et al., 2020d), by 63\% within 12 days in Wuhan (Cole et al., 2020) and by $31.1 \%$ in 10 days in Guangdong (Chen et al., 2021) compared to the period before lockdown. Similarly, by the end of February 2020, $\mathrm{NO}_{2}$ decreased by $64.3 \%$ in Jingmen, $65.2 \%$ in Enshi (Xu et al., 2020a), and by 83\% in Wuhan (Ghahremanloo et al., 2021) compared to February 2019.

Eight out of 10 included articles reported an increase in $\mathrm{O}_{3}$ during lockdown. The median increase was $11.4 \%$, with the highest reported increases in south-western China $(110 \%)$ and in Wuhan (116\%) (Lian et al., 2020) comparing periods before and after lockdown (23 January 2020) 
Table 3. Quantitative summary of the key findings.

\begin{tabular}{|c|c|c|c|c|c|c|c|c|c|c|}
\hline City/Province & Comparison & $A O D$ & $\mathrm{NO}_{2}$ & $\mathrm{PM}_{2.5}$ & $\mathrm{PM}_{10}$ & $\mathrm{SO}_{2}$ & $\mathrm{CO}$ & $\mathrm{O}_{3}$ & $A Q I$ & $\begin{array}{l}\text { First Author } \\
\text { (year) }\end{array}$ \\
\hline \multicolumn{11}{|l|}{ South-western } \\
\hline Anqing & $\begin{array}{l}\text { Feb } 2020 \text { with avg. of Feb } \\
\text { 2017-2019 }\end{array}$ & & 43.8 & 48.6 & 51.9 & 50.2 & 31.8 & 8.2 & & K. Xu (2020) \\
\hline Chengdu & $\begin{array}{l}\text { Feb } 2020 \text { with avg. of Feb } \\
\text { 2017-2019 }\end{array}$ & & 55.9 & 27.9 & 40.2 & 55.8 & 29.6 & 22.5 & & Zhang (2020) \\
\hline Chongqing & $\begin{array}{l}\text { Feb } 2020 \text { with avg. of Feb } \\
\text { 2017-2019 }\end{array}$ & & 63.6 & 18.4 & 27.8 & 78.8 & 37.1 & 3 & & J. Zhang (2020) \\
\hline South-western & $\begin{array}{l}\text { Before } 24 \text { Jan } 2020 \text { with } 24 \\
\text { Jan-9 Feb } 2020\end{array}$ & & 49 & 58 & & 74 & 12 & 230 & & Y. Chen (2020) \\
\hline \multicolumn{11}{|l|}{ Southern } \\
\hline Enshi & Feb 2020 with 2019 & & 65.2 & 15.7 & 25.1 & 35.4 & 35.8 & 6.9 & & K. Xu (2020) \\
\hline $\begin{array}{l}\text { Foshan } \\
\text { (Guangdong) }\end{array}$ & $\begin{array}{l}12 \text { Jan-27 Mar } 2020 \text { with } \\
2019\end{array}$ & & 33 & 32.7 & 36.5 & 27.6 & 29.3 & 15.8 & 19.9 & S. Wan (2020) \\
\hline $\begin{array}{l}\text { Shenzhen } \\
\text { (Guangdong) }\end{array}$ & $\begin{array}{l}12 \text { Jan-27 Mar } 2020 \text { with } \\
2019\end{array}$ & & 20.2 & 16.8 & 13.9 & 6.3 & 15.6 & & 8.2 & S. Wan (2020) \\
\hline Guangdong & $\begin{array}{l}3 \text { Feb } 2020 \text { ( } 5 \text { days before } \\
\text { with } 10 \text { days after) }\end{array}$ & & 31.1 & 9.6 & 11.1 & 5.1 & 16.9 & & & Z. Chen (2021) \\
\hline Guangdong & Jan-April 2020 with 2019 & & 32.38 & 19.82 & 26.41 & 10.32 & 25.69 & & & $\begin{array}{l}\text { A. Shakoor } \\
(2020)\end{array}$ \\
\hline Guangzhou & $\begin{array}{l}12 \text { Jan-27 Mar } 2020 \text { with } \\
2019\end{array}$ & & 30.1 & 31 & 30.2 & 4.2 & 21.8 & 11.4 & 18.1 & S. Wan (2020) \\
\hline Guangzhou & $\begin{array}{l}23 \text { Jan-20 Feb } 2020 \text { with } \\
2019\end{array}$ & & 46 & & & & & & & Z. Pei (2020) \\
\hline $\begin{array}{l}\text { Luzhou } \\
\text { (Sichuan) }\end{array}$ & $\begin{array}{l}\text { Feb } 2020 \text { with avg. of Feb } \\
\text { 2017-2019 }\end{array}$ & & 70 & 7.6 & 23.5 & 105.6 & 11 & 5.6 & & J. Zhang (2020) \\
\hline \multicolumn{11}{|l|}{ Northern } \\
\hline Beijing & Jan-Mar 2020 with 2019 & & 25.2 & & & & & & & J. Nichol (2020) \\
\hline Beijing & Jan-April 2020 with 2019 & & 25.64 & 6.48 & 79.07 & 42.64 & 11.02 & & & $\begin{array}{l}\text { A. Shakoor } \\
(2020)\end{array}$ \\
\hline Beijing & $\begin{array}{l}\text { Jan-Feb } 2020 \text { with avg. of } \\
\text { 2015-2019 }\end{array}$ & & 26.54 & 16.34 & & 37.15 & 32.18 & 18.11 & & Z. Zhang (2020) \\
\hline Beijing & $\begin{array}{l}\text { Mar-Apr } 2020 \text { with avg. of } \\
\text { 2015-2019 }\end{array}$ & & 38.88 & 33.19 & & 48.18 & 40.12 & 10.79 & & Z. Zhang (2020) \\
\hline Beijing & $\begin{array}{l}23 \text { Jan-20 Feb } 2020 \text { with } \\
2019\end{array}$ & & 28 & & & & & & & Z. Pei (2020) \\
\hline Beijing & Mar 2020 with 2019 & & & 50 & & & & & & $\begin{array}{l}\text { A. Chauhan } \\
(2020)\end{array}$ \\
\hline $\begin{array}{l}\text { Beijing-Tianjin- } \\
\text { Hebei }\end{array}$ & Feb 2020 with 2019 & 31 & 54 & & & & 8 & 17 & & $\begin{array}{l}\text { M. } \\
\text { Ghahremanloo } \\
(2021)\end{array}$ \\
\hline $\begin{array}{l}\text { Beijing-Tianjin- } \\
\text { Hebei } \\
\text { (northern } \\
\text { China) }\end{array}$ & $\begin{array}{l}23 \text { Jan-4 Feb } 2020 \text { (10 days } \\
\text { before and after } \\
\text { Lockdown) }\end{array}$ & & 24.67 & 5.93 & 13.66 & 6.76 & 4.58 & & 7.8 & R. Bao (2020) \\
\hline \multicolumn{11}{|l|}{ Eastern } \\
\hline Hangzhou (rural) & $\begin{array}{l}24 \text { Jan-15 Feb } 2020 \text { with } \\
2019\end{array}$ & & 48 & 18.5 & 39.6 & & & 15.7 & & L. Wang (2020) \\
\hline $\begin{array}{l}\text { Hangzhou } \\
\text { (urban) }\end{array}$ & $\begin{array}{l}24 \text { Jan-15 Feb } 2020 \text { with } \\
2019\end{array}$ & & 58.4 & 42.7 & 47.9 & 28.6 & 22.3 & 22.2 & & L. Wang (2020) \\
\hline Hefei (Anhui) & $\begin{array}{l}\text { Feb } 2020 \text { with avg. of Feb } \\
\text { 2017-2019 }\end{array}$ & & 50.2 & 49.2 & 47.4 & 41.7 & 38.6 & 3.3 & & K. Xu (2020) \\
\hline
\end{tabular}


Table 3. (continued).

\begin{tabular}{|c|c|c|c|c|c|c|c|c|c|c|}
\hline City/Province & Comparison & $A O D$ & $\mathrm{NO}_{2}$ & $\mathrm{PM}_{2.5}$ & $\mathrm{PM}_{10}$ & $\mathrm{SO}_{2}$ & $\mathrm{CO}$ & $\mathrm{O}_{3}$ & AQI & $\begin{array}{l}\text { First Author } \\
\text { (year) }\end{array}$ \\
\hline Suzhou (Jiangsu) & $\begin{array}{l}\text { Feb } 2020 \text { with avg. of Feb } \\
\text { 2017-2019 }\end{array}$ & & 64.4 & 41.6 & 47.3 & 65.5 & 38.2 & 0.06 & & K. Xu (2020) \\
\hline Zhejiang & Jan-Apr 2020 with 2019 & & 43.89 & 19.78 & 23.62 & 18.96 & 66.83 & & & $\begin{array}{l}\text { A. Shakoor } \\
(2020)\end{array}$ \\
\hline \multicolumn{11}{|l|}{ Others } \\
\hline $\begin{array}{l}\text { Central, eastern, } \\
\text { and southern } \\
\text { regions }\end{array}$ & $\begin{array}{l}20 \text { Jan-8 Apr } 2020 \text { with } \\
2019\end{array}$ & & & 16 & 20 & & & & & Z. Fan (2020) \\
\hline $\begin{array}{l}\text { North central } \\
\text { China }\end{array}$ & $\begin{array}{l}23 \text { Jan-20 Feb } 2020 \text { with } \\
2019\end{array}$ & & 24 & & & & & & & $\begin{array}{l}\text { S. Griffith } \\
(2020)\end{array}$ \\
\hline $\begin{array}{l}\text { Locked-down } \\
\text { cities and } \\
\text { Wuhan }\end{array}$ & $\begin{array}{l}1 \text { Jan-1 Mar } 2020 \text { with } \\
2019\end{array}$ & & & 24 & & & & & 22 & G. He (2020) \\
\hline \multicolumn{11}{|l|}{ Central } \\
\hline Hubei & 1 week after 23 Jan 2020 & & 48.61 & 11.32 & & & & & & $\begin{array}{l}\text { A. Agarwal } \\
(2020)\end{array}$ \\
\hline Hubei & Jan 2020 with 2019 & & & 20.17 & & & & & & $\begin{array}{l}\text { A. Agarwal } \\
(2020)\end{array}$ \\
\hline Hubei & Feb 2020 with 2019 & & & 26.31 & & & & & & $\begin{array}{l}\text { A. Agarwal } \\
(2020)\end{array}$ \\
\hline Hubei & Mar 2020 with 2019 & & & 9.97 & & & & & & $\begin{array}{l}\text { A. Agarwal } \\
(2020)\end{array}$ \\
\hline Hubei & $\begin{array}{l}24 \text { Jan } 2020 \text { ( } 5 \text { days before } \\
\text { with } 10 \text { days after) }\end{array}$ & & & 23 & 17.1 & & 17 & & & Chen Z. (2021) \\
\hline Hubei & Jan-April 2020 with 2019 & & 49.21 & 16.2 & 31 & 9.33 & 11.02 & & & $\begin{array}{l}\text { A. Shakorr } \\
(2020)\end{array}$ \\
\hline Wuhan & $\begin{array}{l}21 \text { Jan } 2020 \text { ( } 30 \text { days } \\
\text { before with } 12 \text { days } \\
\text { after) }\end{array}$ & & 63 & & 35 & 0 & 0 & & & M. Cole (2020) \\
\hline Wuhan & $\begin{array}{l}21 \text { Jan-8 Apr } 2020 \text { with } \\
2019\end{array}$ & & & 36 & 39 & & & & & Z. Fan (2020) \\
\hline Wuhan & Feb 2020 with 2019 & 62 & 83 & & & 71 & 4 & 50 & & $\begin{array}{l}\text { M. } \\
\text { Ghahremanloo } \\
\text { (2021) }\end{array}$ \\
\hline Wuhan & $\begin{array}{l}23 \text { Jan-13 Feb } 2020 \text { with } \\
\text { avg. 2015-2019 }\end{array}$ & & 93 & 43.5 & & & & & & T. Le (2020) \\
\hline Wuhan & $\begin{array}{l}24 \text { Jan-23 Feb } 2020 \text { with } \\
\quad 2019\end{array}$ & & & & & & & & 47.5 & X. Lian (2020) \\
\hline Wuhan & $\begin{array}{l}4 \text { Dec 2019-23 Jan } 2020 \\
\text { with } 24 \text { Jan-23 Feb } 2020\end{array}$ & & 53.3 & 36.9 & 40.2 & 3.9 & 28 & 116.6 & 33.9 & X. Lian (2020) \\
\hline Wuhan & $\begin{array}{l}24 \text { Dec } 2019-23 \text { Jan } 2020 \\
\text { with } 24 \text { Jan-23 Feb } 2020\end{array}$ & & 53.2 & 29.9 & & & & & & C. Ma (2020) \\
\hline Wuhan & Jan-Mar 2020 with 2019 & & 45 & & & & & & & J. Nichil (2020) \\
\hline Wuhan & $\begin{array}{l}\text { 1-22 Jan } 2020 \text { with } 23 \text { Jan- } \\
29 \text { Feb } 2020\end{array}$ & & 55 & 33 & & & 23 & 108 & & X. Shi (2020) \\
\hline Wuhan & Feb 2020 with 2019 & & 54.7 & 44 & 47.9 & 29.9 & 16.2 & 27.1 & & K. Xu (2020) \\
\hline Wuhan & $\begin{array}{l}23 \text { Jan-8 Apr } 2020 \text { with } \\
\text { avg. of 2017-2019 }\end{array}$ & & 57.2 & 36.3 & 48.7 & & & 37.7 & & P. Sicard (2020) \\
\hline Wuhan & $\begin{array}{l}23 \text { Jan-20 Feb } 2020 \text { with } \\
2019\end{array}$ & & 57 & & & & & & & Z. Pei (2020) \\
\hline Jingmen (Hubei) & Feb 2020 with 2019 & & 64.3 & 30.5 & 48.4 & 34.9 & 31.9 & 8.9 & & K. Xu (2020) \\
\hline
\end{tabular}


Table 3. (continued).

\begin{tabular}{|c|c|c|c|c|c|c|c|c|c|c|}
\hline City/Province & Comparison & AOD & $\mathrm{NO}_{2}$ & $\mathrm{PM}_{2.5}$ & $\mathrm{PM}_{10}$ & $\mathrm{SO}_{2}$ & $\mathrm{CO}$ & $\mathrm{O}_{3}$ & AQI & $\begin{array}{l}\text { First Author } \\
\text { (year) }\end{array}$ \\
\hline \multicolumn{11}{|l|}{ Nationwide } \\
\hline Nationwide & Jan 2020 with Mar 2020 & & & & & & & & 30.95 & Q. Liu (2020) \\
\hline Nationwide & Jan-Feb 2020 with 2019 & & 49 & 37 & & 11 & & & & $\begin{array}{l}\text { M. Marlier } \\
(2020)\end{array}$ \\
\hline Nationwide & $\begin{array}{l}\text { Feb } 2020 \text { with avg. of } \\
\text { 2010-2020 }\end{array}$ & & 25 & & & & & & & $\begin{array}{l}\text { A. Metya } \\
(2020)\end{array}$ \\
\hline Nationwide & $\begin{array}{l}25 \text { Dec } 2019-24 \text { Jan } 2020 \\
\text { with } 24 \text { Jan-25 Feb } 2020\end{array}$ & & & 39.97 & 25.58 & & & & 30.49 & W. Ming (2020) \\
\hline Nationwide & $\begin{array}{l}23 \text { Jan-31 Mar } 2020 \text { with } \\
\text { avg. of 2015-2019 }\end{array}$ & & 27 & 10.5 & 21.4 & & 12.1 & & & B. Silver (2020) \\
\hline Nationwide & $\begin{array}{l}\text { 1-23 Jan } 2020 \text { with } 24 \text { Jan- } \\
\quad 9 \text { Feb } 2020\end{array}$ & & 54 & 21 & 27 & 16 & & & 20 & Y. Wang (2020) \\
\hline Nationwide & Jan-Apr 2020 with 2019 & & 25 & 14.8 & 20.5 & 21.4 & 6.2 & & & $\begin{array}{l}\text { Q. Wang } \\
(2020)\end{array}$ \\
\hline Nationwide & $\begin{array}{l}1 \text { Jan-30 Apr } 2020 \text { with } \\
2019\end{array}$ & & 16 & 14 & 15 & 12 & 12 & 9 & & Q. Chen (2020) \\
\hline Nationwide & $\begin{array}{l}30 \text { days before to } 60 \text { days } \\
\text { after } 25 \text { Jan } 2020\end{array}$ & & 80 & & & 50 & & & & C. Fan (2020) \\
\hline \multicolumn{11}{|l|}{ South-eastern } \\
\hline Shanghai & Jan-April 2020 with 2019 & & 43.78 & 26.6 & 29.14 & 31.19 & 18.21 & & & $\begin{array}{l}\text { A. Shakoor } \\
(2020)\end{array}$ \\
\hline Shanghai & Mar 2020 with 2019 & & & 54.54 & & & & & & $\begin{array}{l}\text { A. Chauhan } \\
(2020)\end{array}$ \\
\hline \multicolumn{11}{|c|}{ Yangtze River Delta region } \\
\hline YRD region & $\begin{array}{l}26 \text { Feb-31 Mar } 2020 \text { with } \\
2019\end{array}$ & & 27.2 & 33.2 & & 7.6 & & & & L. Li (2020) \\
\hline YRD region & $\begin{array}{l}24 \text { Jan-25 Feb } 2020 \text { with } \\
2019\end{array}$ & & 45.1 & 31.8 & & 20.4 & & & & L. Li (2020) \\
\hline YRD region & Jan-Mar 2020 with 2019 & & 30 & & & & 20 & & & $\begin{array}{l}\text { M. Filonchkyk } \\
\text { (2020) }\end{array}$ \\
\hline
\end{tabular}

Note: avg. = average value; with = compared with .

(Table 3). Two studies matched $\mathrm{O}_{3}$ concentration in Wuhan between February 2020 with February 2019 and recorded 50\% (Ghahremanloo et al., 2021) and 27.1\% (Xu et al., 2020a) increases. Zhang et al. (2020b) also showed $10.7 \%$ and $18.1 \%$ drops in $\mathrm{O}_{3}$ concentration in Beijing during March and April 2020 when compared with the average of March and April over the period 2015-2019. The presence of ultraviolet radiations from sunlight or a lack of sunshine in Beijing during the period was the likely cause of this reduction (Zhang et al., 2020b).

In Table 4, the correlation between various measures of air pollutants was analysed. As expected, these pollutants demonstrated a positive relationship when measured against the reported data from the included studies. 10 studies reported changes in AQI, and the percentage changes in AQIs were significantly correlated with the changes in $\mathrm{PM}_{2.5}, \mathrm{NO}_{2}, \mathrm{CO}$ and $\mathrm{PM}_{10}$. As expected, changes in the level of $\mathrm{PM}_{2.5}$ in the air is highly correlated with $\mathrm{PM}_{10}$ and $\mathrm{NO}_{2}$ with $\mathrm{SO}_{2}$.

Table 5 summarises the findings of eight included studies that reported data comparing changes in the air quality for a single geographical area based on different levels of lockdowns or different time periods. Chen et al. (2020d) concluded that air quality improved significantly during Level I (24 January-15 March) compared to Level II (16 March-1 April). Identical findings were reported by Li et al. (2020), who found that reductions in concentration of $\mathrm{PM}_{2.5}$ were $10 \%$ lower in Level II than in Level I. Compared with 2019, the reductions of $\mathrm{NO}_{2}$ were $45.1 \%$ in Level I and $27.2 \%$ in Level II. He et al. (2020) showed that AQI in locked-down cities (19.8) reduced at a higher rate compared to cities that did not have formal lockdowns (6.3). Metya et al. (2020) concluded that China experienced larger reductions in $\mathrm{NO}_{2}$ in February (33\%) than in March (15\%). 
Table 4. Correlation analysis.

\begin{tabular}{lllllll}
\hline & $\mathrm{NO}_{2}$ & $\mathrm{PM}_{2.5}$ & $\mathrm{PM}_{10}$ & $\mathrm{SO}_{2}$ & $\mathrm{CO}$ & $\mathrm{AQI}$ \\
\hline $\mathrm{NO}_{2}$ & 1.00 & & & & & \\
$\mathrm{PM}_{2.5}$ & 0.41 & 1.00 & & & & \\
$\mathrm{PM}_{10}$ & 0.33 & 0.50 & 1.00 & 1.00 & & \\
$\mathrm{SO}_{2}$ & 0.62 & 0.18 & 0.34 & -0.09 & 1.00 & \\
$\mathrm{CO}$ & 0.09 & 0.34 & 0.21 & 0.25 & 0.80 & 1.00 \\
$\mathrm{AQI}$ & 0.83 & 0.87 & 0.78 & & \\
\hline
\end{tabular}

Table 5. Effect of lockdown on air quality at different times and lockdown levels (summary of the key findings).

\begin{tabular}{|c|c|c|c|c|}
\hline $\begin{array}{l}\text { First Author } \\
\text { (year) }\end{array}$ & $\begin{array}{l}\text { Study Setting } \\
\text { and Method }\end{array}$ & Time & Lockdown Stage & Conclusion \\
\hline $\begin{array}{l}\text { Y. Chen } \\
(2020 d)\end{array}$ & $\begin{array}{l}\text { South-western } \\
\text { China; QT }\end{array}$ & 17 January-April 1 & $\begin{array}{l}\text { Level I and II } \\
\text { response to } \\
\text { major public } \\
\text { health } \\
\text { emergencies } \\
\text { (RMPHE) }\end{array}$ & $\begin{array}{l}\text { During the strictest control measures } \\
\text { from the Level I RMPHE to } 9 \text { February } \\
2020, \mathrm{PM}_{2.5}, \mathrm{PM}_{10}, \mathrm{NO}_{2}, \mathrm{SO}_{2} \text {, and } \mathrm{BC} \\
\text { decreased to } 58 \%, 52 \%, 49 \%, 74 \% \text {, and } \\
61 \% \text { respectively; the concentrations } \\
\text { were then restored to } 72 \%, 74 \%, 80 \% \text {, } \\
90 \% \text {, and } 82 \% \text { between } 10 \text { February } \\
\text { and } 15 \text { March (when the Level II } \\
\text { RMPHE was announced). After the } \\
\text { Level II RMPHE, } \mathrm{SO}_{2}, \mathrm{NO}_{2} \text {, and } \mathrm{PM}_{10} \\
\text { rose to } 220 \% \text {, and } 105 \% \text { compared } \\
\text { with before the Level I RMPHE. }\end{array}$ \\
\hline G. He (2020) & Nationwide; QT & 1 January-1 March & $\begin{array}{l}\text { With or without } \\
\text { formal } \\
\text { lockdowns }\end{array}$ & $\begin{array}{l}\text { Within weeks, the AQI in the locked- } \\
\text { down cities was brought down by } \\
19.84 \text { points }\left(\mathrm{PM}_{2.5} \text { down by } 14.07 \mu \mathrm{g}\right. \\
\mathrm{m}^{-3} \text { ) relative to the control group. In } \\
\text { addition, air quality in cities without } \\
\text { formal lockdowns also improved } \\
\text { because of the enforcement of other } \\
\text { types of counter-virus measures. The } \\
\text { AQI in those cities was brought down } \\
\text { by } 6.34 \text { points (PM } 2.5 \text { down by } 7.05 \mu \mathrm{g} \\
\left.\mathrm{m}^{-3}\right) \text { lockdown effects are larger in } \\
\text { colder, richer and more industrialised } \\
\text { cities. }\end{array}$ \\
\hline L. Li (2020) & $\begin{array}{l}\text { YRD region } \\
\text { (Shanghai, } \\
\text { Hangzhou, } \\
\text { Nanjing and } \\
\text { Hefei); QT }\end{array}$ & $\begin{array}{l}\text { Pre-lockdown (1-23 } \\
\text { January), Level I } \\
\text { response (roughly } 24 \\
\text { January-25 February), } \\
\text { Level II response (roughly } \\
26 \text { February-31 March) } \\
\text { and Level III response ( } 31 \\
\text { March onwards) }\end{array}$ & $\begin{array}{l}\text { Pre-lockdown, } \\
\text { Level I } \\
\text { response, } \\
\text { Level II } \\
\text { response, } \\
\text { Level III } \\
\text { response }\end{array}$ & $\begin{array}{l}\text { Concentrations of } \mathrm{PM}_{2.5}, \mathrm{NO}_{2} \text { and } \mathrm{SO}_{2} \\
\text { decreased by } 31.8 \%, 45.1 \% \text { and } 20.4 \% \\
\text { during the Level I period; and } 33.2 \% \text {, } \\
27.2 \% \text { and } 7.6 \% \text { during the Level II } \\
\text { period compared with } 2019 \text {. } \\
\text { Reductions in } \mathrm{PM}_{2.5} \text { concentration in } \\
\text { Level II is approximately } 10 \% \text { lower } \\
\text { than Level I. }\end{array}$ \\
\hline $\begin{array}{l}\text { Q. Liu } \\
\qquad(2020 b)\end{array}$ & Nationwide; QT & & $\begin{array}{l}\text { Monthly average } \\
\text { in January, } \\
\text { February, and } \\
\text { March }\end{array}$ & $\begin{array}{l}\text { The study also discovered a significant } \\
\text { decreasing trend in the daily average } \\
\text { AQI for mainland China from January } \\
\text { to March 2020, with cleaner air in } \\
\text { most provinces during February (60) } \\
\text { and March (54), compared to January } \\
\text { (82) 2020. This is due to shutdown } \\
\text { policies in China around 7-10 February } \\
2020 \text {. }\end{array}$ \\
\hline
\end{tabular}


Table 5. (continued).

\begin{tabular}{|c|c|c|c|c|}
\hline $\begin{array}{l}\text { First Author } \\
\text { (year) }\end{array}$ & $\begin{array}{l}\text { Study Setting } \\
\text { and Method }\end{array}$ & Time & Lockdown Stage & Conclusion \\
\hline $\begin{array}{l}\text { A. Metya } \\
(2020)\end{array}$ & $\begin{array}{l}\text { North-central } \\
\text { China; QT }\end{array}$ & January-April 2020 & $\begin{array}{c}\text { January, February, } \\
\text { March, April }\end{array}$ & $\begin{array}{l}\text { Compared to } 2019 \text {, a } 6.5 \% \text { and } 5.1 \% \\
\text { reduction in CO is observed over north- } \\
\text { central China in February and March } \\
\text { 2020, respectively. } \\
\text { Compared to } 2019 \text {, China experienced a } \\
\text { maximum reduction in } \mathrm{NO}_{2} \text { in February } \\
\text { (33) } 2020 \text {, than reduction in March (15). }\end{array}$ \\
\hline S. Wan (2020) & Foshan; QT & $\begin{array}{l}\text { January, February, } \\
\text { March }\end{array}$ & $\begin{array}{l}\text { Highest AQI days in } \\
\text { January, February } \\
\text { and March }\end{array}$ & $\begin{array}{l}\text { AQI were } 83,85 \text {, and } 72 \text { in mid-January, } \\
\text { February and March, respectively. } \mathrm{PM}_{2.5} \\
\text { were } 42,43, \text { and } 34 \text { in mid-January, } \\
\text { February and March, respectively. } \\
\mathrm{SO}_{2} \text { (ppb) were } 3.5,2.45 \text {, and } 2.10 \text { in mid- } \\
\text { January, February and March, } \\
\text { respectively. CO (ppm) were } 0.88,0.56 \text {, } \\
\text { and } 0.64 \text { in mid-January, February and } \\
\text { March, respectively. }\end{array}$ \\
\hline $\begin{array}{l}\text { L. Wang } \\
\qquad(2020 a)\end{array}$ & $\begin{array}{r}10 \text { urban sites in } \\
\text { Hangzhou; QT }\end{array}$ & January-February & $\begin{array}{l}\text { Before city lockdown, } \\
\text { 1-23 January; } \\
\text { during city } \\
\text { lockdown, } 24 \\
\text { January-15 } \\
\text { February; and } \\
\text { during resumption, } \\
\text { 16-28 February }\end{array}$ & $\begin{array}{l}\text { For the urban area, before the lockdown } \\
\text { period, January } 1-23,2020 / 2019 \\
\text { decreases amounted to } 24.8 \% \text { for } \mathrm{PM}_{2.5} \text {, } \\
19.8 \% \text { for } \mathrm{PM}_{10}, 29.2 \% \text { for } \mathrm{SO}_{2}, 14.1 \% \text { for } \\
\mathrm{CO} \text { and } 13.7 \% \text { for } \mathrm{NO}_{2} \text {. By comparison, } \\
\text { the decreases were much higher during } \\
\text { the lockdown period, } 24 \text { January-15 } \\
\text { February: } 42.7 \% \text { for } \mathrm{PM}_{2.5}, 47.9 \% \text { for } \\
\mathrm{PM}_{10}, 22.3 \% \text { for } \mathrm{CO} \text { and } 58.4 \% \text { for } \mathrm{NO}_{2} \text {, } \\
\text { except for } \mathrm{SO}_{2} \text { ( } 28.6 \% \text { ). } \\
\text { After } 15 \text { February, these trends began to } \\
\text { reverse due to the resumption of work } \\
\text { and production activities and both } \mathrm{PM}_{2.5} \\
\text { and } \mathrm{PM} \mathrm{M}_{10} \text { levels rose to higher values } \\
\text { after resumption. }\end{array}$ \\
\hline K. Xu (2020a) & $\begin{array}{l}\text { Wuhan, } \\
\text { Jingmen, and } \\
\text { Enshi; QT }\end{array}$ & January-March & $\begin{array}{l}\text { January, February, } \\
\text { March }\end{array}$ & $\begin{array}{l}\text { The average air quality index (Xiong et al., } \\
\text { 2020) for Wuhan, Jingmen, and Enshi in } \\
\text { January, February, and March } 2020 \\
\text { were } 32.2 \%, 27.7 \% \text {, and } 14.9 \% \text { lower } \\
\text { than the levels in 2017-2019, } \\
\text { respectively. } \\
\text { The average PM } 2.5 \text { for Wuhan, Jingmen, } \\
\text { and Enshi in January, February, and } \\
\text { March } 2020 \text { were } 36.2 \%, 30.1 \% \text { and } \\
\text { 15.8\% lower than the levels in } 2017- \\
2019 \text {, respectively. }\end{array}$ \\
\hline
\end{tabular}

Note: QT = quantitative study design; $A O D$ = aerosol optical depth.

Furthermore, Wang et al. (2020a) indicated that after 15 February (during resumption of work and production activities) both $\mathrm{PM}_{2.5}$ and $\mathrm{PM}_{10}$ increased in Hangzhou compared to the lockdown periods of 24 January-15 February. The findings from all of these studies demonstrate the immediate impact of COVID-19-related lockdowns on air quality in different parts of China. However, as restrictions were eased in subsequent months the rapid pace of improvement in air quality also receded. On the other hand, Liu et al. (2020b) and Wan et al. (2020) identified lower levels of AQI nationwide and in Foshan, respectively, in March (54 and 34, respectively) compared to January ( 82 and 83 , respectively). 


\subsection{Key Findings in the Included Literature}

The included studies made several important arguments regarding the fluctuations of criteria pollutants in China during COVID-19 lockdown. These studies unanimously concluded that lack of traffic movement due to travel restrictions played an important role in reducing air pollution in China (Agarwal et al., 2020; Bao and Zhang, 2020; Cole et al., 2020; Fan et al., 2020a; Le et al., 2020). Others found curbing industrial production, household consumption, and engineering construction (along with traffic movement) also contributed to improvement in air quality (Fan et al., 2020b; Le et al., 2020; Liu et al., 2020b; Ming et al., 2020; Wan et al., 2020; Zhang et al., 2020a; Zhang et al., 2020b).

Restriction on traffic mobility and industrial activity had a variable impact on different criteria pollutants across China. According to Fan et al. (2020b), lower traffic movement caused more reduction in $\mathrm{PM}_{2.5}$ in east China and $\mathrm{PM}_{10}$ in central China. In contrast, reduced industrial activities contributed to a higher drop in $\mathrm{PM}_{2.5}$ and $\mathrm{PM}_{10}$ in south-western and north-eastern China, respectively. The literature also suggested that urban and densely populated areas had experienced larger reductions in air pollution compared to rural areas (Fan et al., 2020a; Filonchyk et al., 2020; Wang et al., 2020a). In addition, Chen et al. (2020c) found that improvements in air quality was more prominent in north-eastern and inland provinces than in south-eastern coastal and western provinces. Similarly, Pei et al. (2020) concluded that concentration of $\mathrm{PM}_{2.5}$ decreased more in Wuhan (inland) compared to Guangzhou and Beijing and Wang et al. (2020a) found a sharp decrease in the $\mathrm{NO}_{2}$ concentration in urban than in rural areas of Hangzhou. In another study, Liu et al. (2020b) showed higher levels of improvement in air quality in commercial areas compared to residential areas.

Several studies argued the importance of accounting for weather conditions when observing pollution levels (Bao and Zhang, 2020; Chen et al., 2020c; Cole et al., 2020; Fan et al., 2020a; He et al., 2020; Pei et al., 2020; Xu et al., 2020b; Zhang et al., 2020b). For example, Cole et al. (2020) used a two-stage random forests machine learning approach and Bao and Zhang (2020) used a least-square dummy variable method to control for the confounding effects of meteorological conditions from pollution patterns. Noticeably, some included studies did not control for this key factor while measuring air quality. However, all the studies that took weather condition into consideration overwhelmingly concluded that COVID-19 lockdown significantly reduced air pollution in China (Bao and Zhang, 2020; Chen et al., 2020c; Fan et al., 2020a; He et al., 2020; Pei et al., 2020; Xu et al., 2020b; Zhang et al., 2020b).

There was an important distinction between the sources of data among the included studies. One group of studies collected data from satellite sources (Metya et al., 2020; Nichol et al., 2020; Shi and Brasseur, 2020; Sicard et al., 2020; Silver et al., 2020; Wang and Su, 2020; Wang et al., 2020a; Zhang et al., 2020b) and others from ground monitoring stations (Agarwal et al., 2020; Chauhan and Singh, 2020; Chen et al., 2020c; Cole et al., 2020). Marlier et al. (2020) concluded that satellite-based results were in general similar to air quality data from ground monitoring stations.

Lastly, numerous studies have concluded that the reduction in air pollution during COVID-19 whilst welcome is unsustainable for China (Bao and Zhang, 2020; Lian et al., 2020; Liu et al., 2020b; Nichol et al., 2020; Shi and Brasseur, 2020). Furthermore, Nichol et al. (2020) and Sicard et al. (2020) commented that despite the improvements, air quality in some regions in China during lockdown were still below the WHO and EU recommended standards.

\section{DISCUSSION}

The outbreak of COVID-19 pandemic has caused more than a million fatalities globally, which has prompted governments around the world (including China) to take unprecedented actions such as lockdowns of affected cities and regions. Restricting human mobility has assisted in lowering COVID-19 infection, morbidity and mortality. Although lockdown disrupted people's lives and their livelihoods, one of the silver linings was the improvement in air quality globally. In particular, countries such as China, with some of the most polluted cities in the world, experienced significant improvements in air quality immediately following the lockdown. In addition, areas with stringent lockdown responses (Level I or formal lockdowns) experienced greater impact on 
air quality in China, compared to areas that had partial lockdowns. Through this novel systematic review, we attempted to provide a quantitative and narrative synthesis of the recent studies that examined the influence of COVID-19 lockdown on improvement in outdoor air quality in China.

The included studies demonstrated that the measures of air pollutants improved significantly during COVID-9 lockdown. Pollutants such as $\mathrm{PM}_{2.5}, \mathrm{PM}_{10}, \mathrm{NO}_{2}, \mathrm{SO}_{2}$ and $\mathrm{CO}$ dropped, whilst on the contrary, the $\mathrm{O}_{3}$ level increased. The increase in $\mathrm{O}_{3}$ concentration is due to $\mathrm{NO}_{2}$ emissions, and formaldehyde $(\mathrm{HCHO})$ concentrations remaining steady due to the volatile organic compound (VOC) limitations during lockdown (Chen et al., 2020d; Kanniah et al., 2020; Pei et al., 2020; Sicard et al., 2020; Wan et al., 2020; Wang et al., 2020a; Wang et al., 2020c; Xu et al., 2020b). The overall reduction in all air pollutants was attributable to the limited movement of people (Agarwal et al., 2020; Bao and Zhang, 2020; Chauhan and Singh, 2020; Chen et al., 2020d; Cole et al., 2020). 50\% of air pollutant PM (Li et al., 2017), 80\% of CO and 40\% of $\mathrm{NO}_{2}$ (Wang et al., 2008; Xue et al., 2010) in major urban cities of China originate from vehicular exhaustion. Previously, Wang et al. (2017) also found that fossil fuel consumption and transport were the primary elements of air pollution in urban areas of China. Hence, the dramatic reduction in road traffic (e.g., $77 \%$ and $39 \%$ fewer trucks and cars in the Beijing-Tianjin-Hebei region, respectively) played a major role in improving the air quality in China. Temporary suspension of other human activities such as industrial production (Bao and Zhang, 2020; Cole et al., 2020; Fan et al., 2020b) and construction (Li et al., 2020; Lian et al., 2020) were also responsible for the reduction in air pollution.

The findings further demonstrated that urban, industrial and densely populated areas of China experienced major improvements in air quality compared to rural, residential and less populated areas (Chen et al., 2020c; Filonchyk et al., 2020; Wang et al., 2020a). One probable explanation is that metropolitan and industrialised regions with many inhabitants are most likely to have initial poorer air quality (Chen et al., 2020a; Griffith et al., 2020; He et al., 2020; Ghahremanloo et al., 2021). Hence, lockdown measures had a greater effect. Noticeably, as traffic density is high in urban areas, it is highly correlated with $\mathrm{NO}_{2}$ concentration than in rural and less populated areas (Wang et al., 2020a). Since lockdown commenced, the flow of traffic reduced more in urban areas; it contributed to a greater improvement in air quality. Further analysis of the data also indicated that regions that were subject to stricter lockdown (e.g., Hubei Province) had more significant benefits. For example, Wuhan was under lockdown for 76 days, and its improvement in air quality was much higher than other regions (e.g., Beijing and Shanghai). Moreover, inland cities such as Wuhan had a greater reduction in air pollution compared to coastal cities, such as Guangdong. Due to meteorological factors such as high precipitation and wind flow, air pollution in coastal cities is comparatively low compared to inland cities (Chen et al., 2020c; Wan et al., 2020; Chen et al., 2021). Agarwal et al. (2020) show identical findings for coastal and inland states of India.

Three studies compared the variances in the improvement in air quality based on lockdown levels in China (Chen et al., 2020d; He et al., 2020; Li et al., 2020). All of the studies concluded that during the strictest control measures, all components of air quality $\left(\mathrm{PM}_{2.5}, \mathrm{PM}_{10}, \mathrm{NO}_{2}, \mathrm{SO}_{2}\right.$, $\mathrm{CO}$ ) improved significantly compared to areas that had lower levels of restrictions or periods when restrictions were lifted. Others concluded that the reduction in $\mathrm{CO}, \mathrm{NO}_{2}, \mathrm{PM}_{2.5}, \mathrm{SO}_{2}$ were highest immediately after the lockdowns (February 2020) compared with other months (March or April 2020) (Liu et al., 2020a; Metya et al., 2020; Wan et al., 2020; Wang et al., 2020a). This is understandable as stricter lockdowns were associated with extremely low levels of traffic movements, industrial production and other human and economic activities.

It is well documented that weather conditions (e.g., temperature, rain and snowfall, daily maximum and minimum wind speed) play a pivotal role in the concentration of air pollutants (Demuzere et al., 2009; Grange and Carslaw, 2019; Fan et al., 2020a). Several of the included studies accounted for and recorded meteorological factors when indicating the percentage change in concentrations of air pollutants, and the evidence could be regarded as more reliable and complete. Nonetheless, the current study found sufficient evidence of improvement in air quality in China during COVID-19 lockdown irrespective of the changes in weather conditions.

It is important to mention that the level of air pollutants' concentration in China was largely dependent on the time period compared. For example, Sicard et al. (2020) reported that in Wuhan, $\mathrm{NO}_{2}$ reduced by $57.2 \%, \mathrm{PM}_{2.5}$ by $36.3 \%, \mathrm{PM}_{10}$ by $48.7 \%$ and $\mathrm{O}_{3}$ increased by $37.7 \%$ between 23 January to 8 April in 2020 compared to the same period of the average of 2017- 
2019. In contrast, Xu et al. (2020a) concluded that $\mathrm{NO}_{2}$ reduced by $54.7 \%, \mathrm{PM}_{2.5}$ by $44 \%, \mathrm{PM}_{10}$ by 47.9\% and $\mathrm{O}_{3}$ increased by $27.1 \%$ in February 2020 compared to February 2019. Therefore, policymakers and researchers interpreting the changes in air quality data need to pay consideration to this to avoid any misrepresentation of the actual impact of COVID-19 lockdown on air quality Irrespective of this variability, the findings indicate a strong relationship between human economic activity and air quality. A significant improvement in the air quality immediately after the lockdown is an indication that with appropriate policies, efficient use of technology, and by reducing avoidable traffic movement, it is possible to reverse air pollution.

Several key policy implications could be drawn from the findings of our study. First, all the included studies concluded that reducing human activities (road traffic, industrial production, large scale construction etc.) can significantly improve air quality in a short period of time. However, these activities are essential for continuing economic growth. Hence, one area the Chinese government should focus on (to control air pollution) is reducing the consumption of fossil fuel through private vehicle restrictions (Chen et al., 2021; Liu et al., 2020b). The government should invest in improving public transport networks and encourage the use of vehicles with low carbon emission through tax incentives (Wu et al., 2017). Second, during this pandemic, many workers used internet-based virtual technology to conduct meetings and worked from home, which reduced traffic emissions (Han et al., 2020). Further studies are required on how to use digital technology to curb avoidable road traffic movements without compromising human economic activities. A long-term structural change in economic activities could be initiated (e.g., promote working from home and holding teleconferences) that emits less carbon. Third, China has already implemented many environmental policies that were effective in reducing pollution (Chen et al., 2020b; Ming et al., 2020; Venter et al., 2020). Since 2013 one of the key policies was to establish an air quality monitoring system across the country. This has ensured quality and real-time data on the concentrations of air pollutants throughout China. Accurate information is the key to making successful environmental policies. Other developing countries battling with air pollution could learn from the experience of China to generate accurate air quality information which will assist in developing policies related to air quality management. Fourth, for a large and geographically diverse country like China, it is important to be flexible in implementing environmental policies in different regions. Due to the level of industrialisation, population density and variation in meteorological factors, the concentration of air pollutants differs across China. The policy that is fit for a coastal region might not be appropriate or effective in an inland region. Lastly, future studies should use long-term data from specific regions to understand the exact long-run impact of COVID-19 lockdown in different regions in China. It is important to understand whether length or measures (strict to liberal) of lockdown or weather conditions (e.g., temperature, rainfall) played an important role in reducing air pollution during the lockdown. This will assist in implementing an effective air quality management plan in the future.

Some limitations of this systematic literature review are as follows. First, due to significant differences in the study design, statistical estimation and categories of treatment measured in the selected studies, it was not feasible to conduct a meta-analysis. Second, this study excluded all grey literature, report or non-English language articles. One downside of including published articles only is that studies with null findings has a limited probability of being accepted. Therefore, similar to past systematic reviews, this study could not avoid the likelihood of publication bias. Third, this study did not conduct any forward searching; hence, it difficult to judge whether all potential studies have been included in the review despite all the systematic effort. Lastly, the final search was conducted on the 20 September 2020. Any publication after that that was not included in this study.

\section{CONCLUSIONS}

This qualitative systematic review provides a narrative synthesis of the reported changes in air quality across China due to COVID-19-related lockdowns. Owing to the restrictions imposed on human activities, air pollution, led by traffic-related $\mathrm{NO}_{2}$, decreased significantly within a short period. However, the improvement in air quality varied by location: urban, industrial and densely populated areas experienced the largest gains, but inland regions also showed higher reductions 
in pollution than costal ones. Additionally, the percentage of decrease in the air pollution depended strongly on the periods chosen for comparison.

Compared to less stringent measures, full lockdowns produced considerably greater effects on the environment. Furthermore, meteorological factors, such as rainfall and temperature, strongly influenced the concentrations of pollutants in an area, although several of the eligible studies failed to address the role of weather conditions in their measurement results. The air pollutant data appeared to be consistent between the satellites and the ground-level monitoring stations, but the lack of identical studies precluded us from statistically verifying this agreement. Lastly, the lockdown-driven improvements in air quality will be insufficient as well as unsustainable unless strict, region-specific environmental policies are implemented.

Despite the limitations of the eligible studies, our review elucidates the relationship between economic activity and air pollution. Future research should continue investigating this link by focusing on specific activities and areas as well as incorporating meteorological factors (e.g., sunlight or rainfall) into estimates of pollutant concentrations. Finally, additional qualitative and quantitative studies should be conducted to assess the role of ground-level monitoring stations, which may enable other severely polluted regions to replicate China's progress in air quality management.

\section{ADDITIONAL INFORMATION}

The authors of this study declare the following:

Ethics Approval and Consent to Participate

Not applicable as the study is a systematic literature review.

\section{Consent for Publication \\ Not applicable.}

\section{Availability of Data and Materials \\ Not applicable.}

\section{Competing Interests or Conflict Of Interest}

The authors of this study declare that they have no competing interest. The authors have no affiliations with or involvement in any organisation or entity with any financial interest (such as honoraria; educational grants; participation in speakers' bureaus; membership, employment, consultancies, stock ownership, or other equity interest; and expert testimony or patentlicensing arrangements) or non-financial interest (such as personal or professional relationships, affiliations, knowledge or beliefs) in the subject matter or materials discussed in this manuscript.

Rezwanul Hasan Rana declares no conflict of interest.

Syed Afroz Keramat declares no conflict of interest.

Jeff Gow declares no conflict of interest.

\section{Funding}

No funding was received by the authors of this study for this research study.

\section{Acknowledgements}

The research librarians of the University of Southern Queensland for assisting in developing the search terms.

\section{Authorship Contribution Statement}

RHR: worked on conceptualisation, developing methodology, and writing-original draft. SAK: conducted formal analysis. JG: writing-review and editing. 


\section{SUPPLEMENTARY MATERIAL}

Supplementary material for this article can be found in the online version at https://doi.org/ 10.4209/aaqr.200614

\section{REFERENCES}

Agarwal, A., Kaushik, A., Kumar, S., Mishra, R.K. (2020). Comparative study on air quality status in Indian and Chinese cities before and during the COVID-19 lockdown period. Air Qual. Atmos. Health 13, 1167-1178. https://doi.org/10.1007/s11869-020-00881-z

BAO, R., Zhang, A. (2020). Does lockdown reduce air pollution? Evidence from 44 cities in northern China. Sci. Total Environ. 731, 139052. https://doi.org/10.1016/j.scitotenv.2020.13 9052

Cardona, M., Kretschmer, T., Strobel, T. (2013). ICT and productivity: Conclusions from the empirical literature. Inf. Econ. Policy 25, 109-125. https://doi.org/10.1016/j.infoecopol.20 12.12.002

Chauhan, A., Singh, R.P. (2020). Decline in $\mathrm{PM}_{2.5}$ concentrations over major cities around the world associated with COVID-19. Environ. Res. 187, 109634. https://doi.org/10.1016/j.env res.2020.109634

Chen, J., Wang, B., Huang, S., Song, M. (2020a). The influence of increased population density in China on air pollution. Sci. Total Environ. 735, 139456. https://doi.org/10.1016/j.scitotenv. 2020.139456

Chen, K., Wang, M., Huang, C., Kinney, P.L., Anastas, P.T. (2020b). Air pollution reduction and mortality benefit during the COVID-19 outbreak in China. Lancet Planet Health 4, e210-e212. https://doi.org/10.1016/S2542-5196(20)30107-8

Chen, Q.X., Huang, C.L., Yuan, Y., Tan, H.P. (2020c). Influence of COVID-19 event on air quality and their association in mainland China. Aerosol Air Qual. Res. 20, 1541-1551. https://doi.org/ 10.4209/aaqr.2020.05.0224

Chen, Y., Zhang, S., Peng, C., Shi, G., Tian, M., Huang, R. J., Guo, D., Wang, H., Yao, X., Yang, F. (2020d). Impact of the COVID-19 pandemic and control measures on air quality and aerosol light absorption in Southwestern China. Sci. Total Environ. 749, 141419. https://doi.org/10.1 016/j.scitotenv.2020.141419

Chen, Z., Hao, X., Zhang, X., Chen, F. (2021). Have traffic restrictions improved air quality? A shock from COVID-19. J. Cleaner Prod. 279, 123622. https://doi.org/10.1016/j.jclepro.2020.123622

Cole, M.A., Elliott, R.J.R., Liu, B. (2020). The impact of the Wuhan Covid-19 lockdown on air pollution and health: A machine learning and augmented synthetic control approach. Environ. Resour. Econ. 76, 553-580. https://doi.org/10.1007/s10640-020-00483-4

Dantas, G., Siciliano, B., França, B.B., Da Silva, C.M., Arbilla, G. (2020). The impact of COVID-19 partial lockdown on the air quality of the city of Rio de Janeiro, Brazil. Sci. Total Environ. 729, 139085. https://doi.org/10.1016/j.scitotenv.2020.139085

Demuzere, M., Trigo, R., Vila-Guerau de Arellano, J., van Lipzig, N. (2009). The impact of weather and atmospheric circulation on $\mathrm{O}_{3}$ and $\mathrm{PM}_{10}$ levels at a rural mid-latitude site. Atmos. Chem. Phys. 9, 2695-2714. https://doi.org/10.5194/acp-9-2695-2009

Dong, R., Fisman, R., Wang, Y., Xu, N. (2019). Air pollution, affect, and forecasting bias: Evidence from Chinese financial analysts. J Financ. Econo. 139, 971-984. https://doi.org/10.1016/j.jfin eco.2019.12.004

Fan, C., Li, Y., Guang, J., Li, Z., Elnashar, A., Allam, M., de Leeuw, G. (2020a). The impact of the control measures during the COVID-19 outbreak on air pollution in China. Remote Sens. 12, 1613-1613. https://doi.org/10.3390/rs12101613

Fan, Z., Zhan, Q., Yang, C., Liu, H., Zhan, M. (2020b). How did distribution patterns of particulate matter air pollution $\left(\mathrm{PM}_{2.5}\right.$ and $\left.\mathrm{PM}_{10}\right)$ change in china during the COVID-19 outbreak: $A$ spatiotemporal investigation at chinese city-level. Int. J. Environ. Res. Public Health 17, 1-19. https://doi.org/10.3390/ijerph17176274

Fernandez-Montero, J.V., Soriano, V., Barreiro, P., De Mendoza, C., ArtachO, M.Á. (2020). Coronavirus and other airborne agents with pandemic potential. Curr. Opin. Environ. Sci. 
Health 17, 41-48. https://doi.org/10.1016/j.coesh.2020.09.001

Filonchyk, M., Hurynovich, V., Yan, H., Gusev, A., Shpilevskaya, N. (2020). Impact assessment of COVID-19 on variations of $\mathrm{SO}_{2}, \mathrm{NO}_{2}, \mathrm{CO}$ and $\mathrm{AOD}$ over east China. Aerosol Air Qual. Res. 20, 1530-1540. https://doi.org/10.4209/aaqr.2020.05.0226

Gautam, S. (2020). The influence of COVID-19 on air quality in India: A boon or inutile. Bull. Environ. Contam. Toxicol. 104, 724-726. https://doi.org/10.1007/s00128-020-02877-y

Ghahremanloo, M., Lops, Y., Choi, Y., Mousavinezhad, S. (2021). Impact of the COVID-19 outbreak on air pollution levels in East Asia. Sci. Total Environ. 754, 142226. https://doi.org/10.1016/ j.scitotenv.2020.142226

Grange, S.K., Carslaw, D.C. (2019). Using meteorological normalisation to detect interventions in air quality time series. Sci. Total Environ. 653, 578-588. https://doi.org/10.1016/j.scitotenv.2 018.10.344

Griffith, S.M., Huang, W.S., Lin, C.C., Chen, Y.C., Chang, K.E., Lin, T.H., Wang, S.H., Lin, N.H. (2020). Long-range air pollution transport in East Asia during the first week of the COVID-19 lockdown in China. Sci. Total Environ. 741, 140214. https://doi.org/10.1016/j.scitotenv.2020.140214

Han, P., Cai, Q., Oda, T., Zeng, N., Shan, Y., Lin, X., Liu, D. (2020). Assessing the recent impact of COVID-19 on carbon emissions from China using domestic economic data. Sci. Total Environ. 750, 141688. https://doi.org/10.1016/j.scitotenv.2020.141688

He, G., Pan, Y., Tanaka, T. (2020). The short-term impacts of COVID-19 lockdown on urban air pollution in China. Nat. Sustain. 3, 1005-1011. https://doi.org/10.1038/s41893-020-0581-y

IQAIR (2020). 2019 World Air Quality Report: Region \& City PM2.5 Ranking. https://www.iqair.co $\mathrm{m} /$ world-most-polluted-cities

Johns Hopkins University (2021). COVID-19 Dashboard by the Center for Systems Science and Engineering (CSSE). Coronavirus Research Centre, Johns Hopkins University, USA.

Kanniah, K. D., Kamarul Zaman, N.A.F., Kaskaoutis, D.G., Latif, M.T. (2020). COVID-19's impact on the atmospheric environment in the Southeast Asia region. Sci. Total Environ. 736, 139658. https://doi.org/10.1016/j.scitotenv.2020.139658

Le, T., Wang, Y., Liu, L., Yang, J., Yung, Y.L., Li, G., Seinfeld, J.H. (2020). Unexpected air pollution with marked emission reductions during the COVID-19 outbreak in China. Science 369, 702706. https://doi.org/10.1126/science.abb7431

Li, L., Li, Q., Huang, L., Wang, Q., Zhu, A., Xu, J., Liu, Z., Li, H., Shi, L., Li, R., Azari, M., Wang, Y., Zhang, X., Liu, Z., Zhu, Y., Zhang, K., Xue, S., Ooi, M.C.G., Zhang, D., Chan, A. (2020). Air quality changes during the COVID-19 lockdown over the Yangtze River Delta Region: An insight into the impact of human activity pattern changes on air pollution variation. Sci. Total Environ. 732, 139282. https://doi.org/10.1016/j.scitotenv.2020.139282

Li, S., Feng, K., Li, M. (2017). Identifying the main contributors of air pollution in Beijing. J. Cleaner Prod. 163, S359-S365. https://doi.org/10.1016/j.jclepro.2015.10.127

Lian, X., Huang, J., Huang, R., Liu, C., Wang, L., Zhang, T. (2020). Impact of city lockdown on the air quality of COVID-19-hit of Wuhan city. Sci. Total Environ. 742, 140556. https://doi.org/10.1 016/j.scitotenv.2020.140556

Liu, Q., Harris, J.T., Chiu, L.S., Sun, D., Houser, P.R., Yu, M., Duffy, D.Q., Little, M.M., Yang, C. (2020a). Spatiotemporal impacts of COVID-19 on air pollution in California, USA. Sci. Total Environ. 750, 141592. https://doi.org/10.1016/j.scitotenv.2020.141592

Liu, Q., Sha, D., Liu, W., Houser, P., Zhang, L., Hou, R., Lan, H., Flynn, C., Lu, M., Hu, T., Yang, C. (2020b). Spatiotemporal patterns of COVID-19 impact on human activities and environment in Mainland China using nighttime light and air quality data. Remote Sens. 12, 1576. https://doi.org/10.3390/rs12101576

Marlier, M.E., Xing, J., Zhu, Y.F., Wang, S.X. (2020). Impacts of COVID-19 response actions on air quality in China. Environ. Res. Commun. 2, 075003. https://doi.org/10.1088/2515-7620/aba425

Mcinnes, M.D., Moher, D., Thombs, B.D., Mcgrath, T.A., Bossuyt, P.M., Clifford, T., Cohen, J.F., Deeks, J.J., Gatsonis, C., HoofT, L. (2018). Preferred reporting items for a systematic review and meta-analysis of diagnostic test accuracy studies: The PRISMA-DTA statement. JAMA 319, 388396. https://doi.org/10.1001/jama.2017.19163

Metya, A., Dagupta, P., Halder, S., Chakraborty, S., Tiwari, Y.K. (2020). COVID-19 lockdowns improve air quality in the south-east Asian regions, as seen by the remote sensing satellites. Aerosol Air Qual. Res. 20, 1772-1782. https://doi.org/10.4209/aaqr.2020.05.0240 
Ming, W., Zhou, Z., Ai, H., Bi, H., Zhong, Y. (2020). COVID-19 and air quality: Evidence from China. Emerg. Mark. Finance Trade 56, 2422-2442. https://doi.org/10.1080/1540496X.2020.1790353

Nichol, J.E., Bilal, M., Ali, A.M., Qiu, Z. (2020). Air pollution scenario over China during COVID-19. Remote Sens. 12, 2100. https://doi.org/10.3390/rs12132100

Pei, Z., Han, G., Ma, X., Su, H., Gong, W. (2020). Response of major air pollutants to COVID-19 lockdowns in China. Sci. Total Environ. 743, 140879. https://doi.org/10.1016/j.scitotenv.2020. 140879

Shaffril, H.A.M., Krauss, S.E., Samsuddin, S.F. (2018). A systematic review on Asian's farmers' adaptation practices towards climate change. Sci. Total Environ. 644, 683-695. https://doi.org/ 10.1016/j.scitotenv.2018.06.349

Shakoor, A., Chen, X., Farooq, T.H., Shahzad, U., Ashraf, F., Rehman, A., Sahar, N., Yan, W. (2020). Fluctuations in environmental pollutants and air quality during the lockdown in the USA and China: Two sides of COVID-19 pandemic. Air Qual. Atmos. Health. 13, 1335-1342. https://doi.org/10.1007/s11869-020-00888-6

Shi, X., Brasseur, G.P. (2020). The response in air quality to the reduction of chinese economic activities during the COVID-19 outbreak. Geophys. Res. Lett. 47, e2020GL088070. https://doi.org/10.1029/2020GL088070

Sicard, P., De Marco, A., Agathokleous, E., Feng, Z., Xu, X., Paoletti, E., Rodriguez, J.J.D., Calatayud, V. (2020). Amplified ozone pollution in cities during the COVID-19 lockdown. Sci. Total Environ. 735, 139542. https://doi.org/10.1016/j.scitotenv.2020.139542

Silver, B., He, X., Arnold, S.R., Spracklen, D.V. (2020). The impact of COVID-19 control measures on air quality in China. Environ. Res. Lett. 15, 084021. https://doi.org/10.1088/1748-9326/ab a3a2

Venter, Z.S., Aunan, K., Chowdhury, S., Lelieveld, J. (2020). COVID-19 lockdowns cause global air pollution declines. PNAS 117, 18984-18990. https://doi.org/10.1073/pnas.2006853117

von Elm, E., Altman, D.G., Egger, M., Pocock, S.J., Gøtzsche, P.C., Vandenbroucke, J.P. (2007). Strengthening the reporting of observational studies in epidemiology (STROBE) statement: Guidelines for reporting observational studies. BMJ 335, 806-808. https://doi.org/10.1136/ bmj.39335.541782.AD

Wan, S., Cui, K., Wang, Y.F., Wu, J.L., Huang, W.S., Xu, K., Zhang, J. (2020). Impact of the COVID-19 event on trip intensity and air quality in southern China. Aerosol Air Qual. Res. 20, 1727-1747. https://doi.org/10.4209/aaqr.2020.07.0364

Wang, H., Chen, C., Huang, C., Fu, L. (2008). On-road vehicle emission inventory and its uncertainty analysis for Shanghai, China. Sci. Total Environ. 398, 60-67. https://doi.org/10.1016/j.scitote nv.2008.01.038

Wang, J., Du, G. (2020). COVID-19 may transmit through aerosol. Ir. J. Med. Sci. 189, 1143-1144. https://doi.org/10.1007/s11845-020-02218-2

Wang, L., Li, M., Yu, S., Chen, X., Li, Z., Zhang, Y., Jiang, L., Xia, Y., Li, J., Liu, W., Li, P., Lichtfouse, E., Rosenfeld, D., Seinfeld, J.H. (2020a). Unexpected rise of ozone in urban and rural areas, and sulfur dioxide in rural areas during the coronavirus city lockdown in Hangzhou, China: implications for air quality. Environ. Chem. Lett. 18, 1713-1723. https://doi.org/10.1007/s10311-020-01028-3

Wang, L.Q., Li, M.Y., Yu, S.C., Chen, X., Li, Z., Zhang, Y.B., Jiang, L.H., Xia, Y., Li, J.L., Liu, W.P., Li, P.F., Lichtfouse, E., Rosenfeld, D., Seinfeld, J.H. (2020b). Unexpected rise of ozone in urban and rural areas, and sulfur dioxide in rural areas during the coronavirus city lockdown in Hangzhou, China: Implications for air quality. Environ. Chem. Lett. 18, 1713-1723. https://doi.org/10.10 07/s10311-020-01028-3

Wang, Q., Su, M. (2020). A preliminary assessment of the impact of COVID-19 on environment A case study of China. Sci. Total Environ. 728, 138915. https://doi.org/10.1016/j.scitotenv.20 20.138915

Wang, S., Yu, S., Yan, R., Zhang, Q., Li, P., Wang, L., Liu, W., Zheng, X. (2017). Characteristics and origins of air pollutants in Wuhan, China, based on observations and hybrid receptor models. J. Air Waste Manage. Assoc. 67, 739-753. https://doi.org/10.1080/10962247.2016.1240724

Wang, Y., Yuan, Y., Wang, Q., Liu, C., Zhi, Q., Cao, J. (2020c). Changes in air quality related to the control of coronavirus in China: Implications for traffic and industrial emissions. Sci. Total Environ. 731, 139133. https://doi.org/10.1016/j.scitotenv.2020.139133

World Bank (2017). World Development Indicators 2017. World Bank, Washington, DC. 
World Health Organisation (WHO) (2016). Mortality and burden of disease from ambient air pollution. Global Health Observatory (GHO) data.

Wu, Y., Zhang, S., Hao, J., Liu, H., Wu, X., Hu, J., Walsh, M.P., Wallington, T.J., Zhang, K.M., Stevanovic, S. (2017). On-road vehicle emissions and their control in China: A review and outlook. Sci. Total Environ. 574, 332-349. https://doi.org/10.1016/j.scitotenv.2016.09.040

Xiong, J., Lipsitz, O., Nasri, F., Lui, L.M.W., Gill, H., Phan, L., Chen-Li, D., lacobucci, M., Ho, R., Majeed, A., Mcintyre, R.S. (2020). Impact of COVID-19 pandemic on mental health in the general population: A systematic review. J. Affect. Disord. 277, 55-64. https://doi.org/10.1016/j.jad.2 020.08.001

Xu, K., Cui, K., Young, L.H., Hsieh, Y.K., Wang, Y.F., Zhang, J., Wan, S. (2020a). Impact of the COVID19 event on air quality in central China. Aerosol Air Qual. Res. 20, 915-929. https://doi.org/1 0.4209/aaqr.2020.04.0150

Xu, K., Cui, K., Young, L.H., Wang, Y.F., Hsieh, Y.K., Wan, S., Zhang, J. (2020b). Air quality index indicatory air pollutants and impact of COVID-19 event on the air quality near central china. Aerosol Air Qual. Res. 20, 1204-1221. https://doi.org/10.4209/aaqr.2020.04.0139

Xue, J., Tian, W., Zhang, Q. (2010). Development of $\mathrm{NO}_{\mathrm{x}}$ emission inventory from motor vehicles in Hangzhou and study on its influence on air quality. Res. Environ. Sci. 23, 613-618. https://doi.org/10.1016/j.atmosenv.2008.02.010

Zhang, J., Cui, K., Wang, Y.F., Wu, J.L., Huang, W.S., Wan, S., Xu, K. (2020a). Temporal variations in the air quality index and the impact of the COVID-19 event on air quality in Western China. Aerosol Air Qual. Res. 20, 1552-1568. https://doi.org/10.4209/aaqr.2020.06.0297

Zhang, Z., Arshad, A., Zhang, C., Hussain, S., Li, W. (2020b). Unprecedented temporary reduction in global air pollution associated with COVID-19 forced confinement: A continental and city scale analysis. Remote Sens. 12, 2420-2420. https://doi.org/10.3390/rs12152420 